\title{
IDENTIFIKASI PERUBAHAN CURAH HUJAN DAN SUHU UDARA MENGGUNAKAN RCLIMDEX DI WILAYAH SERANG
}

\author{
Nizar Manarul Hidayat ", Alexander Eggy Pandiangan, Anggitya Pratiwi \\ Prodi Klimatologi, Sekolah Tinggi Meteorologi Klimatologi dan Geofisika, Tangerang Selatan \\ *Email:nmanarul@gmail.com
}

\begin{abstract}
ABSTRAK
Data iklim dianalisis untuk mengidentifikasi perubahan besaran parameter iklim maupun peristiwa iklim ekstrem. Data yang menjadi kajian berasal dari Stasiun Meteorologi Serang, Banten. Tujuan penelitian ini adalah menganalisis karakterisktik data cuaca stasiun pengamatan cuaca Serang terutama pada suhu udara dan curah hujan serta mengidentifikasi perubahan pada pola dan nilai kedua parameter tersebut. Pengolahan data dilakukan dengan menggunakan RClimdex untuk mengetahui adanya perubahan jangka panjang suhu dan curah hujan. Secara keseluruhan slope indeks suhu udara pada stasiun pengamatan Serang mengalami penurunan diantaranya indeks TX10p dan TN10p, yang mengindikasikan jumlah hari dengan suhu minimum pada siang hari dan malam hari mengalami penurunan. Pada stasiun Serang slope indeks suhu udara (TN90p) cenderung meningkat yang mengindikasikan suhu minimum lebih hangat. Indeks curah hujan hampir seluruhnya mengalami penurunan kecuali CDD yang menunjukkan peningkatan jumlah hari tanpa hujan berturut-turut di wilayah Serang.
\end{abstract}

Kata kunci: curah hujan, indeks suhu udara, indeks curah hujan, RClimdex, suhu udara

\section{ABSTRACT}

Climate data were analyzed to determine the of changes of climate parameters value or extreme climate events. Data which are investigated on this study come from Serang Banten Meteorological Station. The purpose of this research is to analyze the climate characteristic of weather of Serang observation station especially in air temperature and rainfall and to identify any changes in temperature and precipitation pattern at those observation stations. Data processing was done by using $R$-Climdex to detect the long-term change in temperature and precipitation. The results show that the slope of the air temperature index at the Serang observation station has decreased, namely TX10p and TN1Op indexes, which indicating the number of cold days during the day and night has decreased. At Serang station the air temperature index slope (TN90p) tends to increase indicating warmer air temperatures. The rainfall index almost entirely decreased except CDD which showed increasing of dry day series at Serang region.

Keywords: air temperature, air temperature indices, precipitation, precipitation indices, $R$-climdex

\section{PENDAhUluan}

Salah satu fokus utama peneliti di bidang sains atmosfer beberapa tahun terakhir adalah kajian isu perubahan iklim. Intergovernmental Panel on Climate Change (IPCC) pada assessment report yang ke 4 menunjukkan terjadinya peningkatan suhu udara rata-rata global yang diperkirakan mencapai $0,74^{\circ} \mathrm{C}$ dalam kurun waktu 100 tahun terakhir (1906-2005) (IPCC, 2007). Analisis terkait peristiwa ekstrem penting dilakukan utamanya di wilayah negara berkembang yang rentan terhadap bencana akibat peristiwa ekstrem, salah satunya Indonesia (Hainez dan Patz, 2004).

Berada di wilayah tropis menjadikan Indonesia memiliki curah hujan tinggi dan pencahayaan matahari yang intens setiap tahunnya. Kondisi tersebut juga disertai tingginya resiko bencana akibat peristiwa iklim ekstrem seperti banjir dan kemarau. 
Peningkatan suhu global diperkirakan akan menyebabkan perubahan-perubahan yang lain seperti naiknya permukaan air laut, meningkatnya intensitas fenomena cuaca ekstrem, serta perubahan jumlah dan pola presipitasi (Fox, 2007). Presipitasi sebagai endapan air dari atmosfer pada permukaan bumi dalam bentuk cair (tetes hujan) dan padat (es). Bentuk presipitasi yang umum dikenal adalah hujan (rain), gerimis (drizzle), salju (snow), dan batu es (hail). Di wilayah tropis seperti Indonesia, presipitasi lebih didefinisikan sebagai hujan karena sangat jarang dalam bentuk es (Bayong, 1999).

Dengan adanya kondisi kejadian cuaca ekstrem yang meningkat, maka hal tersebut telah mendorong dikembangkannya penelitian terhadap kejadian cuaca atau iklim ekstrem oleh ilmuwan dunia di dalam Expert Team for Climate Change Detection and Indices (ETCCDI). ETCCDI menyediakan penentuan indeks iklim ekstrem berdasarkan data harian suhu dan curah hujan.

Pertanyaan yang muncul adalah apakah perubahan-perubahan variabel iklim global serta-merta pula diikuti oleh perubahannya di tingkat regional atau lokal. Untuk menjawab pertanyaan tersebut, maka perlu dilakukan kajian data variabel iklim secara lokal. Kenaikan suhu permukaan bumi yang dikenal dengan global warmin menyebabkan perubahan pola iklim. Perubahan pola iklim ini menyebabkan tidak menentunya kondisi iklim adalah perubahan distribusi curah hujan baik secara spasial maupun temporal serta memicu peningkatan peluang kejadian cuaca dan iklim ektrem (Trenberth, 2006).

Banyaknya dampak negatif yang diakibatkan oleh perubahan iklim sehingga diperlukan kegiatan mitigasi (dalam bentuk pengurangan gas rumah kaca) dan adaptasi (dalam bentuk strategi pembangunan yang dapat mereduksi dampak negatif perubahan iklim). Tak dapat diragukan lagi bahwa kota-kota akan memainkan peranan penting dalam pembentukan ekonomi negara-negara berkembang. Kota-kota juga sedang dan akan menghadapi setumpuk permasalahan yang terkait dengan daya dukung dan kerusakan lingkungan fisik. Pertumbuhan populasi yang meningkat tiap tahun dan tidak didukung dengan infrastruktur yang memadai maka kerentanan terhadap dampak perubahan iklim akan semakin tinggi.
Pada makalah ini dilakukan pengujian perubahan variabel iklim seperti temperatur, curah hujan dari pengamatan dan model iklim yang memenuhi kriteria perubahan iklim. Dipilih kota Serang karena merupakan salah satu kota padat di Provinsi Banten. Tujuan dari penelitian ini untuk mengetahui perubahan karakteristik suhu dan curah hujan dari hasil pengamatan di Stasiun Meteorologi Serang Banten 1981-2017 dengan menggunakan perhitungan indeks. Hasil dari penelitian ini untuk kajian akademik yang lebih dalam menyusunan strategi adaptasi dan mitigasi perubahan iklim. Kajian ini haruslah berlandaskan kepada kajia kerentanan dan risiko harus yang berdasarkan pada pola dan besaran perubahan iklim pada lokasi yang spesifik, baik pada waktu sekarang maupun yang akan datang.

\section{METODE PENELITIAN}

Lokasi yang dijadikan objek penelitian adalah Provinsi Banten. Propinsi Banten secara geografis terletak di antara $106^{\circ}$ Bujur Timur dan $6^{\circ}$ Lintang Selatan.

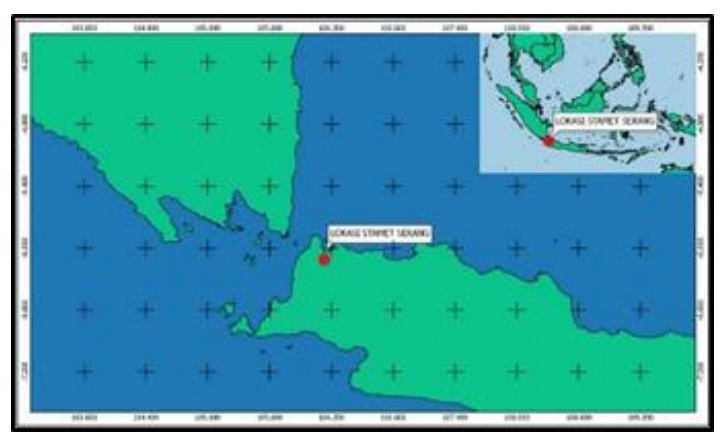

Gambar 1. Lokasi Penelitian Stasiun Meteorologi Serang, Banten

Dalam penelitian ini menggunakan data curah hujan dan temperatur harian di Stasiun Meteorologi Serang, Banten. Tahap awal pada penelitian adalah melakukan pengumpulan data cuaca harian di stasiun pengamatan Meteorologi Serang pada periode pengamatan 1981-2017. Kemudian dilakukan penyusunan data sesuai dengan format pada Rclimdex. Pada tahap ini data yang telah diperoleh diolah dengan menggunakan software pengolah data statistik untuk mendapatkan grafik karakteristik parameter cuaca dengan cara perhitungan ratarata 30 hari.

RClimdex merupakan aplikasi berbahasa $\mathrm{R}$ yang dikembangkan oleh Climate Research 
Branch of Meteorological Service of Cananda yang digunakan untuk mendeteksi dan memonitoring perubahan iklim dengan fokus utama pada kejadian-kejadian ekstrem (Zhand dan Feng, 2004). Rclimdex memiliki 27 indeks iklim, 16 diantaranya merupakan indeks suhu (Tabel 1) sedangkan 11 indeks lainnya merupakan indeks presipitasi (Tabel 2). Secara umum, sebagian besar indeks dapat diterapkan untuk setiap wilayah dunia, namun beberapa indeks tertentu tidak signifikan ketika perbedaan iklim antara wilayah diperhitungkan (Tebaldi dkk., 2006).
Data yang diperoleh diolah pada RClimdex dengan format input data berupa ASCII text file. Susunan data pada file yang akan diolah adalah: tahun, bulan, hari, presipitasi, suhu maksimum, suhu minimum secara harian. Satuan yang digunakan untuk curah hujan adalah millimeter, dan untuk suhu adalah derajat celcius. Jika ditemukan data kosong, maka data tersebut diisi dengan nilai -99.99. Setelah melakukan kontrol kualitas pada data, Rclimdex akan mengolah data secara komputasi berdasarkan 27 indeks yang tersedia.

Tabel 1. Indeks suhu dalam RClimdex

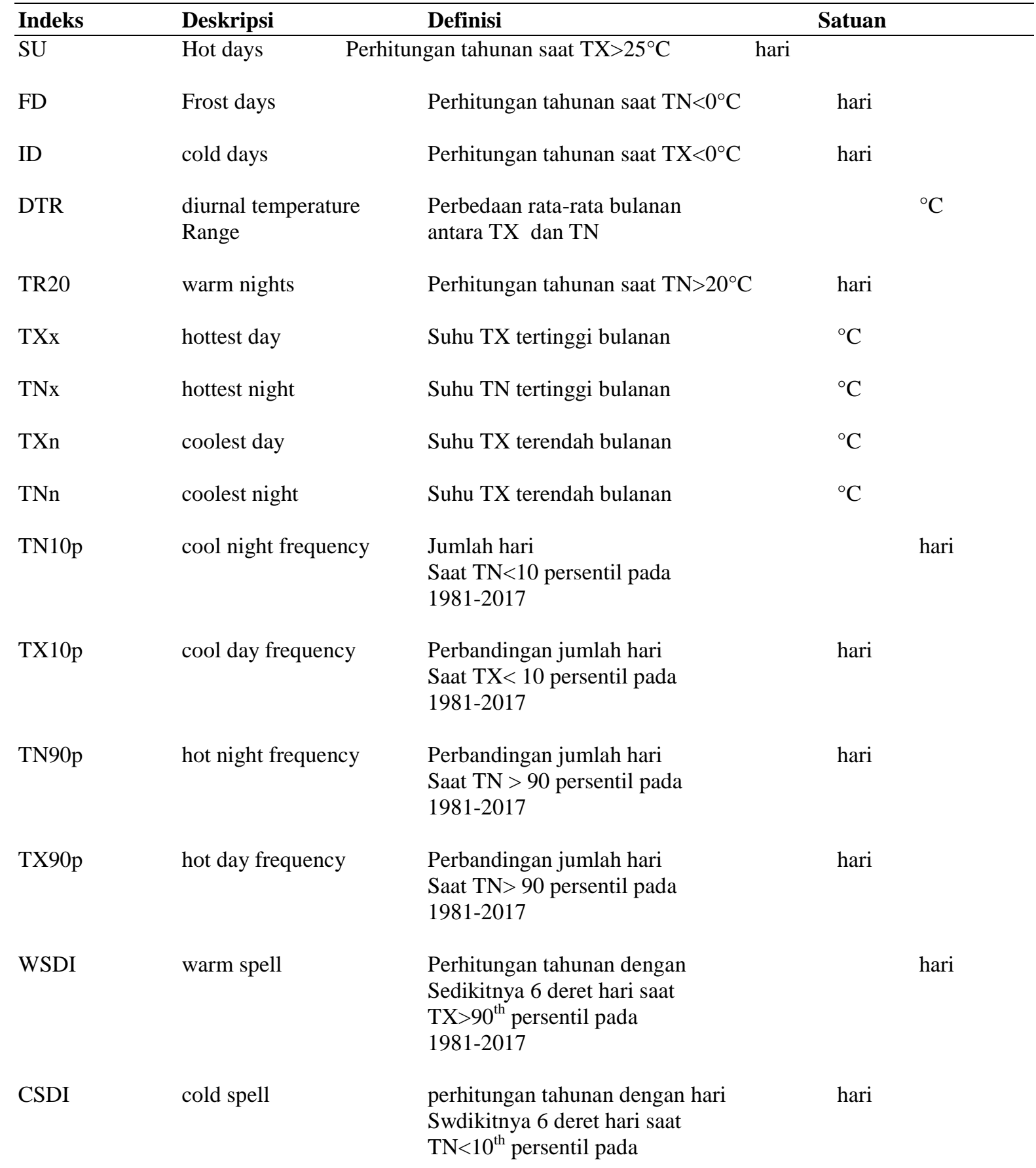


$1981-2017$

GSL growing season length

Perhitungan tahunan antara

hari awal span sedikitnya 6 hari dengan $\mathrm{TG}>5^{\circ} \mathrm{C}$ setelah musim dingin dan awal span setelah musim panas selama 6 hari dengan $\mathrm{TG}<5^{\circ} \mathrm{C}$

Tabel 2 Indeks curah hujan dalam Rclimdex

\begin{tabular}{|c|c|c|c|}
\hline Indeks & Deskrpsi & Definisi & Satuan \\
\hline PRCPTOT & wet day precipitation & $\begin{array}{l}\text { Total presipitasi tahunan } \\
\text { Dari hari basah }\end{array}$ & $\mathrm{mm}$ \\
\hline $\mathrm{SDH}$ & $\begin{array}{l}\text { Simple daily } \\
\text { Intensity index }\end{array}$ & $\begin{array}{l}\text { Rata-rata presipitasi pada } \\
\text { pada hari basah }\end{array}$ & $\mathrm{mm} /$ hari \\
\hline CDD & consecutive dry days & $\begin{array}{l}\text { Nilai maksimum darin deret } \\
\text { Hari kering }\end{array}$ & hari \\
\hline CWD & $\begin{array}{l}\text { consecutive wet } \\
\text { Days }\end{array}$ & $\begin{array}{l}\text { Nilai maksimum dari deret } \\
\text { hari basah }\end{array}$ & hari \\
\hline $\mathrm{R} 10 \mathrm{~mm}$ & $\begin{array}{l}\text { heavy precipitation } \\
\text { Days }\end{array}$ & $\begin{array}{l}\text { Perhitungan jumlah hari } \\
\text { secara tahunan saat } \mathrm{RR}>= \\
20\end{array}$ & hari \\
\hline $\mathrm{R} 20 \mathrm{~mm}$ & $\begin{array}{l}\text { very heavy } \\
\text { Precipitation daysseca }\end{array}$ & $\begin{array}{l}\text { Perhitungan jumlah hari } \\
\text { hunan saat } R R>= \\
20\end{array}$ & hari \\
\hline Rnnmmb & $\begin{array}{l}\text { number of days } \\
\text { Above nn mm }\end{array}$ & $\begin{array}{l}\text { Perhitungan jumlah hari } \\
\text { secara tahunan saat PRCP } \\
>=\text { nn mm, nn adalah } \\
\text { Threshold yang ditentukan }\end{array}$ & hari \\
\hline R95p & $\begin{array}{l}\text { very wet day } \\
\text { Precipitation }\end{array}$ & $\begin{array}{l}\text { jumlah presipitasi tahunan } \\
\text { ketika RR> } 95 \text { persentil dari } \\
\text { 1981-2017 curah hujan }\end{array}$ & $\mathrm{mm}$ \\
\hline R99p & $\begin{array}{l}\text { extremely wet day } \\
\text { Precipitation }\end{array}$ & $\begin{array}{l}\text { jumlah presipitasi tahunan } \\
\text { ketika RR }>=99 \text { persentil dari } \\
1981-2017 \text { curah hujan } \\
\text { harian }\end{array}$ & $\mathrm{mm}$ \\
\hline \multicolumn{4}{|c|}{ RX1day maximum 1-day Presipitasi maksimum $\quad \mathrm{mm}$} \\
\hline \multicolumn{4}{|c|}{$\begin{array}{lll}\text { RX5day maximum 5-day Presipitasi maksimum } & \mathrm{mm} \\
\text { Precipitation } & \text { Tahunan per-5 hari } & \end{array}$} \\
\hline
\end{tabular}


Adapun metode yang digunakan dalam penelitian ini adalah sebagai berikut:

a. Metode Rata-Rata (mean)

Metode ini didapatkan dari menjumlahkan seluruh data $\left(\sum \mathrm{Xi}\right)$, kemudian dibagi dengan banyaknya data $(\mathrm{n})$ pada data tersebut (Pribadi dan Yanuar, 2012):

$$
\bar{X}=\frac{1}{2} \sum_{i=1}^{n} X_{i}
$$

dimana,

$\mathrm{X}=$ nilai rata - rata curah hujan estimasi $(\mathrm{mm})$

$\mathrm{Xi}=$ nilai curah hujan pada beberapa titik estimasi 1, 2, 3, dan 4 (mm)

$\mathrm{n}$ = banyaknya data

\section{b. Metode Regresi Linier}

Kecenderungan (trend) temporal dari masingmasing indeks dalam periode 1981-2017 dapat diketahui dari hasil perhitungan kemiringan (slope) menggunakan metode Least Square. Metode Least Square bertujuan untuk mendapatkan koefisien regresi a dan b, yang menjadikan jumlah kuadrat error sekecil mungkin (Ariantono, 2015). Adapun persamaan regresi linier adalah sebagai berikut.

$$
y_{i}=a+b_{x}
$$

dimana,

$x_{i}=$ variabel bebas

$y_{i}=$ variabel terikat

$a=$ nilai rata-rata pada variabel y apabila variabel $\mathrm{x}$ bernilai 0

$b=$ koefisien regresi (slope) variabel $\mathrm{x}$

Perhitungan ini dilakukan dengan menggunakan aplikasi RClimdex dapat diunduh pada (www.r-project.org). Selanjutnya, dilakukan uji tingkat kepercayaan terhadap kecenderungan (trend) menggunakan metode uji Mann-Kendall. Adapun prosedur untuk analisis Mann-Kendall dikutip HydroGeoLogic, Inc (2005), yaitu sebagai berikut:

a. Menghitung statistik Mann-Kendall
Nilai awal (initial value) statistik Mann-Kendall (S) diasumsikan 0 (misalnya tidak ada kecenderungan). Jika nilai data dari periode waktu setelahnya lebih tinggi dari nilai data periode waktu sebelumnya, $\mathrm{S}$ ditambah 1 . Sebaliknya, jika nilai data dari periode waktu setelahnya lebih rendah dari nilai data periode sebelumnya, S dikurangi dengan 1. Hasil dari semua tahap menghasilkan nilai akhir dari S.

Rumus untuk menghitung $\mathrm{S}$ yaitu:

$$
S=\sum_{k=1}^{n-1} \sum_{j=k+1}^{n} \operatorname{sign}\left(x_{j}-x_{k}\right)
$$

dimana,

$$
\begin{array}{r}
\operatorname{sign}\left(x_{j}-x_{k}\right)= \\
\left\{\begin{array}{c}
1, \text { if }\left(x_{j}-x_{k}\right)>0 \\
0, \text { if }\left(x_{j}-x_{k}\right)=0 \\
-1, \text { if }\left(x_{j}-x_{k}\right)<0
\end{array}\right.
\end{array}
$$

b. Menghitung uji statistik $\mathrm{Z}$ normalisasi sebagai berikut:

$$
Z=\left\{\begin{array}{l}
\frac{s-1}{\sqrt{\operatorname{Var}(S)}}, \text { if } S>0 \\
0, \text { if } S=0 \\
\frac{s+1}{\sqrt{\operatorname{Var}(S)}}, \text { if } S<0
\end{array}\right.
$$

c. Menghitung probabilitas yang terkait dengan uji statistik normalisasi ini, dinyatakan dalam nilai-p ( $p$-value). Fungsi densitas probabilitas untuk distribusi normal dengan rata-rata 0 dan deviasi standar 1 diberikan oleh persamaan berikut:

$$
\begin{aligned}
& f(z)=\frac{1}{\sqrt{2 \pi}} e^{-\frac{z^{2}}{2}} \\
& p-\text { value }=1-f(z)
\end{aligned}
$$

d. Menentukan tingkat signifikansi (alpha $=$ $5 \%)$. 
Kesimpulan mengenai kecenderungan ditentukan menggunakan kriteria, yaitu kecenderungan dikatakan menurun jika $\mathrm{Z}$ bernilai negatif dan dikatakan meningkat jika $\mathrm{Z}$ bernilai positif. Kecenderungan signifikan

\section{HASIL DAN PEMBAHASAN}

\subsection{Analisis Trend}
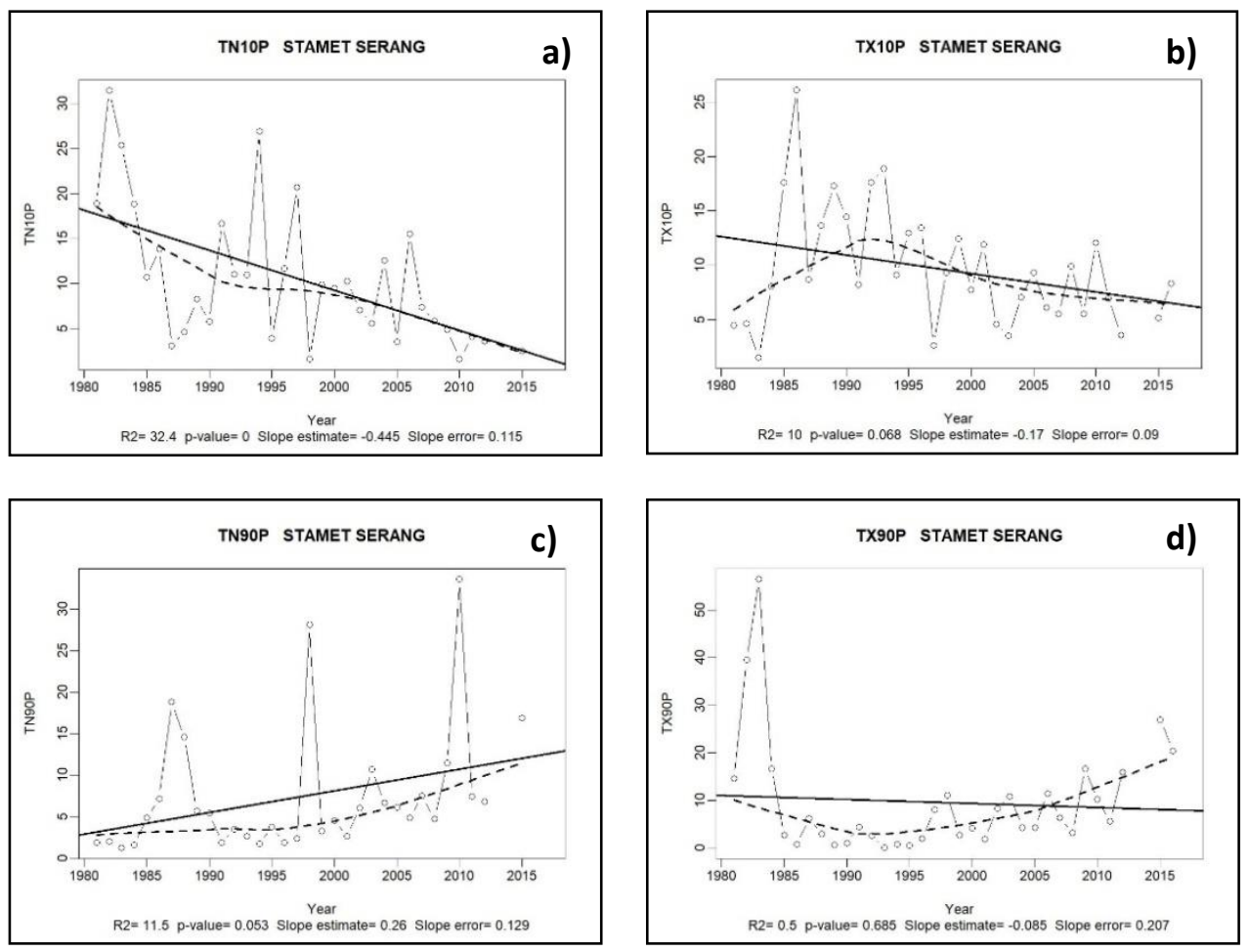

Gambar 3.1 Trend suhu: a) TN10p; b) TX10p; c) TN90p dan d) TX90p wilayah Serang tahun 1981-2017

Gambar 3.1 menunjukkan trend indeks TN10P, TX10P, TN90P, dan TX90P. Berdasarkan gambar tersebut terlihat bahwa indeks yang memiiliki trend menurun adalah indeks TN10P, TX10P, dan TX90P. Adapun dari ketiga indeks tersebut, indeks yang trend menurunnya signifikan adalah indeks TN10P. Sedangkan indeks yang memiliki trend yang meningkat adalah TN90P.

Berdasarkan Gambar 3.1 diketahui bahwa indeks TN10P memiliki indeks yang menurun secara signifikan. Hal ini berarti bahwa telah terjadi penurunan jumlah hari dingin di malam hari secara signifikan di Serang. Terjadinya penurunan trend jumlah hari dengan suhu minimum pada malam hari karena adanya secara statistik jika $p$-value kurang dari alpha, sebaliknya berarti kecenderungan tidak signifikan atau tidak ada kecenderungan. 

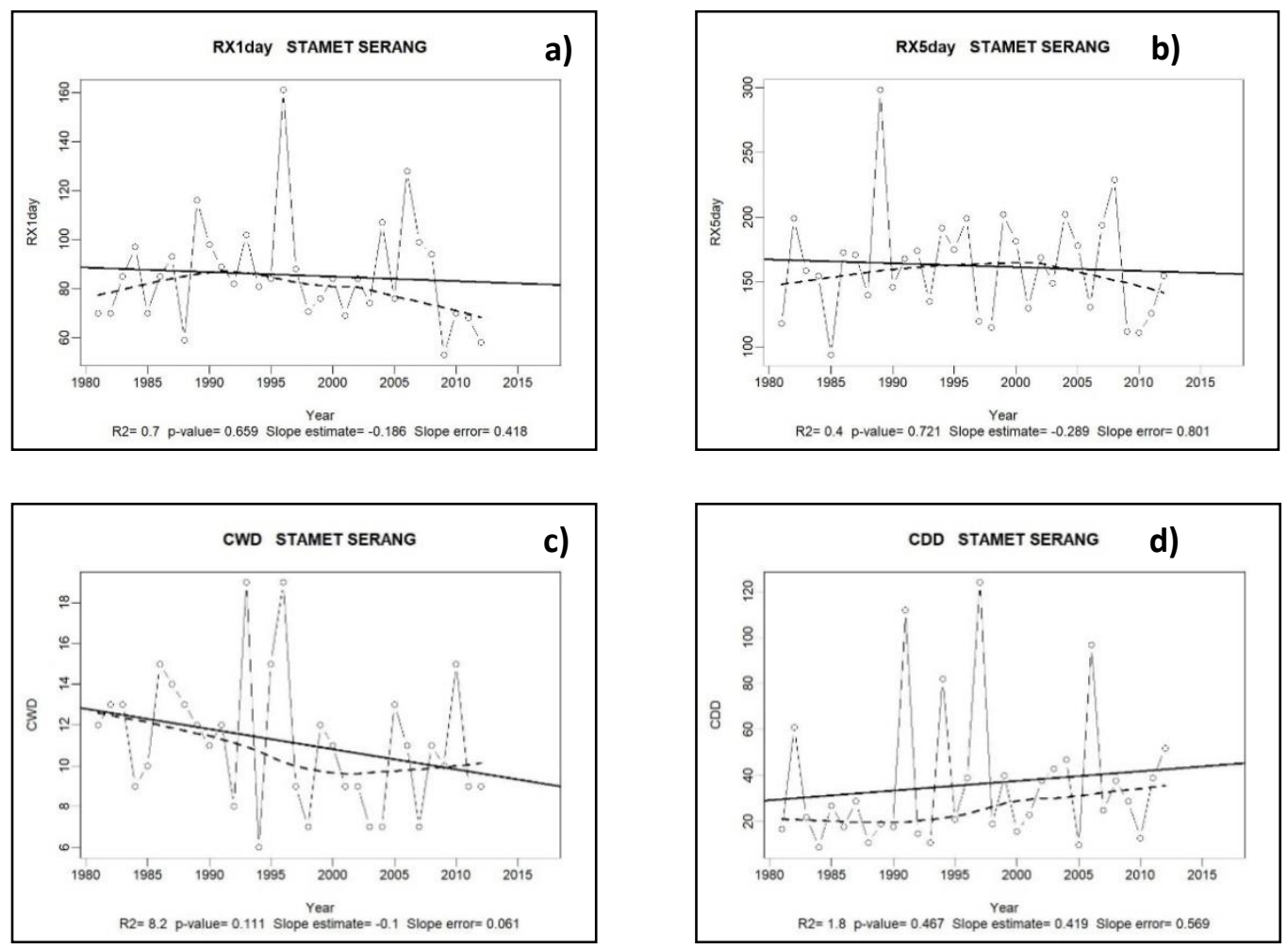

Gambar 3.2 Trend presipitasi: a) RXIday; b) RX5day dan hari hujan; c) CWD; d) CDD periode 1981- 2017 di wilayah Serang

Trend curah hujan ekstrem yang terjadi di Serang dapat dilihat dengan adanya penurunan yang tidak signifikan pada indeks Rxlday dan Rx5day. Penurunan pada kedua indeks tersebut menunjukkan bahwa curah hujan harian dan lima harian di Serang memiliki intensitas yang semakin ringan dari tahun ke tahun. Semakin ringan kondisi curah

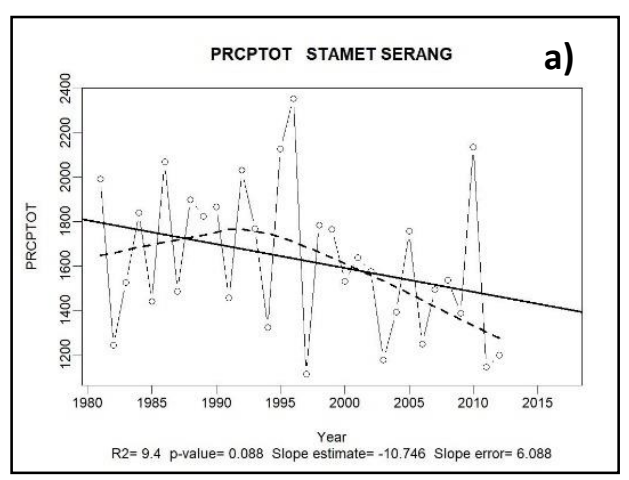

hujan harian ataupun lima harian, maka akan mengakibatkan trend CWD menurun dan trend CDD meningkat. Berdasarkan Gambar 3.2 terlihat bahwa meskipun penurunan trend pada indeks Rxlday dan Rx5day tidak signifikan, namun hal tersebut sudah dapat menyebabkan indeks CWD dan CDD mengalami perubahan yang cukup signifikan.

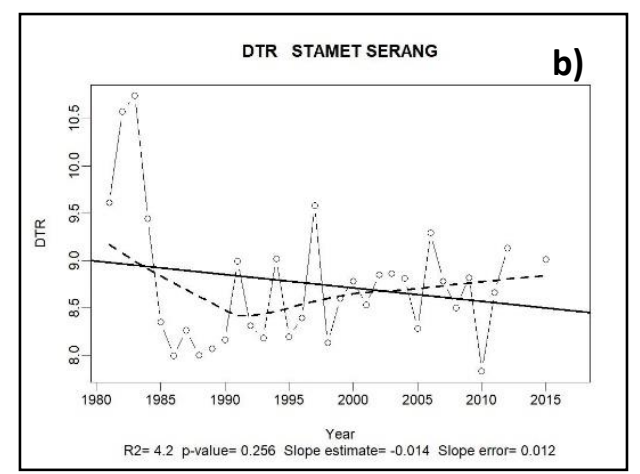

Gambar 3.3 Trend presipitasi dan selisih suhu: a) PRCPTOT; b) DTR di wilayah Serang tahun 1981-2017 
Berdasarkan Gambar 3.3.a terlihat bahwa indeks PRCPTOT memiliki trend negatif, yang berarti bahwa jumlah curah hujan tahunan di Serang memiliki trend yang menurun dengan laju penurunan $10.746 \mathrm{~mm}$ per tahun. Curah hujan tahunan terbesar terjadi pada tahun 1996 yaitu sebesar $2353 \mathrm{~mm}$ sedangkan terkecil pada tahun 1997 sebesar $1111 \mathrm{~mm}$. Berdasarkan data NOAA tahun 1996 terjadi La-Nina kuat pada Agustus 1995 sampai dengan Maret 1996 dan tahun 1997 terjadi El-Nino kuat sampai dengan Mei 1998.

Gambar 3.3.b menunjukkan bahwa indeks DTR memiliki trend yang menurun. Hal tersebut menunjukkan bahwa selisih antara suhu maksimum rata-rata bulanan dengan suhu minimum rata-rata bulanan semakin kecil. Selisih yang semakin kecil tersebut dapat mengindikasikan bahwa suhu maksimum ratarata bulanan dengan suhu minimum rata-rata bulanan tidak memiliki perbedaan yang begitu jauh. Sehingga dari hal tersebut dapat diketahui bahwa suhu minimum rata-rata bulanan di Serang semakin tinggi.

\section{KESIMPULAN}

Dari 18 Indeks iklim maka didapatkan bahwa perubahan signifikan hanya terjadi pada indeks TN10p. Secara keseluruhan indeks suhu udara menunjukkan slope menurun yaitu TX90p, TX10p, dan TN10p. Untuk indeks curah hujan tidak terjadi perubahan yang berarti.

\section{UCAPAN TERIMA KASIH}

Ucapan terimakasih ditujukan kepada semua pihak telah membantu terciptanya makalah ini. Pertama ditujukan untuk Bapak Dr. Agus Safril, S.T, M.MT yang telah membantu menyumbangkan ide untuk penulisan ini. Kedua ditujukan untuk Anggitya Pratiwi selaku Penulis ketiga yang telah meluangkan waktu setelah menerima tamu dari seseorang yang belum diketahui jawabannya sampai sekarang.

\section{DAFTAR PUSTAKA}

IPCC, Intergovernmental Panel on Climate Change. 2007. IPCC Fourth Assessment Report: Climate Change 2007, (https://www.ipcc.ch/publications_and_d ata/ar4/wg1/en/ch3s3-8-5.html), diakses 31 Oktober 2017.

Haines, P. A. 2004. Health effects of climate change. Journal of the Ameican Medical Association 291 (1):99-103.

FoxNews,(http://www.foxnews.com/story/2007/ 09/04/nasa-global-warming-tocausemore-severe-tornadoes-storms.html), diakses tanggal 10 Desember 2017.

Bayong, T. H. K. 1999. Klimatologi Umum. Bandung: ITB.

Trenberth, K. 2006. Estimates of the Global Water Budgets and Its annual Cycle Using Observation and Model Data. Journal of Hydrometeorology.

Zhang X., dan Feng Y. 2004. RClimdex 1.0 User Manual. Climate Research Branch Environment Canada:Ontario.

Tebaldi C., Hayhoe K., Arblaster J. M., dan Meehl G. A. 2006. Going to the extremes. An intercomparisonof modelsimulated historical and future changes in extreme events. Climatic Change 79:185211.

Pribadi, Y. H. 2012. Variabilitas Curah Hujan dan Pergeseran Musim Di Wilayah Banten Sehubungan Dengan Variasi Suhu Muka Laut Perairan Indonesia, Samudera Pasifik dan Samudera Hindia. Tesis Program Magister Ilmu Geografi. Fakultas Matematika dan Ilmu Pengetahuan Alam. Universitas Indonesia, Depok.

Ariantono, J.Y. 2015, Pemetaan Indeks Iklim Ekstrim di Provinsi Aceh Menggunakan Data TRMM dan Aphrodite, Tesis, Program Studi Magister Ilmu Kebencanaan, Universitas Syiah Kuala Darussalam, Banda Aceh.

Hydro GeoLogic, Inc. 2005. Appendix D: Mann Kendall Analysis, Annual Groundwater Monitoring Report, California. 
